\title{
PIERWSZY NUMER „ALARMU” JÓZEFA MACKIEWICZA I BARBARY TOPORSKIEJ ODNALEZIONY
}

\author{
Janusz KLEMENS (Gdańsk) \\ ORCID: 0000-0002-9794-3958
}

Michał Bąkowski w szkicu Wstęp do bibliografii, czyli o roli donosów policyjnych w badaniach literackich ${ }^{1}$ napisał w ostatnim, podsumowującym zdaniu: „Nadal jednak, pomimo wieloletnich poszukiwań, nie udało się znaleźć podziemnego pisma »Alarm« wydawanego przez Józefa i Barbarę Mackiewiczów w Warszawie w 1944 roku"². Wydrukowane egzemplarze nowego wydania NUDIS VERBIS zostały w październiku 2017 roku skierowane do dystrybucji krajowej. W tym samym czasie powiadomiłem panią Ninę Karsov o odnalezieniu pierwszego numeru „Alarmu”. W nocie od Wydawcy pani Nina Karsov napisała:

[...] Wobec tego nadzwyczajnego zbiegu zdarzeń, postanowiłam wstrzymać dystrybucję Nudis Verbis i wydać suplement. Nie ma wątpliwości, że Janusz Klemens prawidłowo zidentyfikował Alarm $[\ldots]^{3}$

\footnotetext{
${ }^{1}$ J. Mackiewicz, Nudis Verbis, Londyn 2017, s. 533-565.

${ }^{2}$ M. Bąkowski, tamże, s. 565.

${ }^{3}$ N. Karsov, Od Wydawcy, [w:] J. Mackiewicz, Nudis verbis. SUPLEMENT, Londyn 2017, s. 3.
} 


\section{Proweniencja egzemplarza}

Pierwszy numer „Alarmu”, datowany na 24 czerwca 1944 roku, został odnaleziony w zbiorach Chełmskiej Biblioteki Publicznej pod sygnaturą ChBP-PK-7. Pochodzi z prywatnych zbiorów Jana Szczawieja (1906-1963), poety, działacza konspiracyjnego Stronnictwa Ludowego „Roch”, a po wojnie ZSL. Chełmska Biblioteka Publiczna zakupiła znaczną część jego kolekcji od wdowy w latach 80. Wśród wielu tytułów prasy konspiracyjnej znajdował się egzemplarz „Alarmu”. Przez wiele lat trzymano go w prohibitach, ale od 2004 roku udostępniany jest w czytelni, zaś od 2011 roku w wersji cyfrowej. Biblioteka nic nie wie o innych numerach tej publikacji. Na podstawie danych zawartych w Centralnym Katalogu Polskiej Prasy Konspiracyjnej (Wydawnictwo Ministerstwa Obrony Narodowej, 1962) „Alarm” został zakwalifikowany przez chełmskich bibliotekarzy jako wydawane na przełomie 1944 i 1945 roku pismo Narodowych Sił Zbrojnych „Alarm!” — jego egzemplarze znajdują się w Archiwum Akt Nowych i Bibliotece Narodowej. Wykrzyknik w tytule, a przede wszystkim treść, świadczą o tym, że „Alarm” i „Alarm!” nie są tożsame, zatem kwalifikacja dokonana przez Chełmską Bibliotekę Publiczną jest błędna.

Oryginalny egzemplarz „Alarmu” jest zachowany w dobrym stanie. Składa się z 16 stron zwartego druku maszynowego, 8 kartek formatu A4 obustronne zadrukowanych, które nie są ze sobą połączone. Zachowały się ślady po zszywkach. Na pierwszej stronie papier, w miejscu gdzie były zszywki, jest lekko naderwany, poplamiony i nadkruszony. Są tam niewielkie usterki, które nie przeszkadzają w odczytaniu treści. Pozostałe strony są mniej zniszczone. „Alarm” został powielony prawdopodobnie metodą „sitodruku” na zwykłym papierze maszynowym. Druk jest miejscami mniej, a miejscami bardziej wyraźny, zaś ostatnie dwie kartki są ciemniejsze niż pozostałe. Prawdopodobnie jest to wina papieru lub sposobu przechowywania czasopisma.

Określenie odnalezionego „Alarmu” jako dzieła Józefa Mackiewicza i Barbary Toporskiej zostało oparte na trzech zasadniczych przesłankach:

1. podtytuł: „Nadpartyjny organ do walki z bolszewizmem”;

2. analogie do tekstów Józefa Mackiewicza zamieszczonych w: broszurze Optymizm nie zastapi nam Polski ${ }^{4}$; tekstach publicystycznych: Spotkanie z Lipińskim ${ }^{5}, \mathrm{Nu}$ dis Verbis ${ }^{6}$;

3. część haseł zamieszczonych w „Alarmie” pochodzi z broszury Bilans czterolecia 1939-1944 wydanej w styczniu 1944 roku, której autorem był ppłk Wacław Lipiński, podpisujący się jako GWIDO ${ }^{7}$.

\section{Kontekst}

Z chwilą, gdy Armia Czerwona przekroczyła przedwojenną granicę Rzeczpospolitej, rozpoczęła się realizacja planu „Burza”. W tym czasie Polska miała zerwane stosunki dyplomatyczne ze Związkiem Sowieckim w reakcji na zaangażowanie się Rządu Rzeczpospolitej w zbadanie odpowiedzialności za zbrodnię katyńską. Pozostali nam sojusznicy - Wielka Brytania i USA, którzy decydują wraz z Sowietami w Teheranie i Jałcie o przyszłości m.in. ziem polskich bez konsultacji lub choćby powiadomienia Rządu RP na uchodźstwie. Żołnierze Armii Krajowej współpracujący z Armią Czerwo-

\footnotetext{
${ }_{5}^{4}$ J. Mackiewicz, Optymizm nie zastapi nam Polski, Dzieła, t. 18, Londyn 2015.

${ }^{5}$ Tenże, Spotkanie z Lipińskim, [w:] Nudis verbis, Londyn 2017, s. 519-526.

${ }^{6}$ Tenże, Nudis verbis, [w:] Nudis verbis, s. 452-467.

${ }^{7}$ GWIDO (Wacław Lipiński), Bilans czterolecia 1939-1944, Warszawa — styczeń 1944
} 
ną w ramach operacji „Burza” byli masowo aresztowani przez Sowietów. Na terenach polskich zajmowanych przez Armię Czerwoną rozpoczynał się kolejny z rzędu oficjalny proces sowietyzacji. W takim momencie Mackiewiczowie postanowili wydawać czasopismo „Alarm”. Pierwszy numer pojawił się w kolportażu z datą 24 czerwca 1944 roku.

\section{Treść i przesłanie}

Co postuluje? Kim są autorzy? Największa trudność tkwi w identyfikacji. Każdy trop może okazać się zarówno prawdziwy, jak i fałszywy. Zważywszy na warunki konspiracyjne, grono współpracowników było ograniczone do minimum, a zakres treściowy odbiegał od oficjalnego tonu czasopism sygnowanych przez Armię Krajową i inne struktury podziemia niepodległościowego. Wśród rozpoznanych autorów znajdują się: Józef Mackiewicz, Barbara Toporska, ppłk Wacław Lipiński ${ }^{8}$, Aleksander Bocheński.

$\mathrm{W}$ poniższym zestawieniu przedstawiam zakres treściowy każdego z odrębnych tekstów wraz z domniemanym autorstwem. W oryginale, co wydaje się oczywiste, materiały nie były podpisane, więc przypisane autorstwo ma charakter hipotetyczny. Zastosowałem metodę porównawczą, biorąc pod uwagę wskazówki zawarte w broszurze Optymizm nie zastapi nam Polski oraz artykułach Józefa Mackiewicza nawiązujących do publikowanego „Alarmu”. Na przykład długo zastanawiałem się nad sygnaturą X.Y., którą podpisano się pod tekstem „Wolnej Trybuny”; był to jedyny podpis na szesnastu stronach pisma. Kilka tropów prowadzących do osób związanych z Narodową Demokracją, a jednocześnie będących w kręgu czynnych znajomości Mackiewicza, które wydawały się prawie pewne, okazały się fałszywe. Ostatecznie autorem okazał się Aleksander Bocheński, o czym później.

Aby przedstawić pełen zakres treści obecnych w pierwszym numerze „Alarmu”, zastosowałem następujące zasady. Każda z osobnych sekwencji tekstowych została oznaczona numerem, zgodnie z kolejnością nadaną przez Mackiewiczów, w nawiasie okrągłym umieściłem zakres stron, na których znajduje się sekwencja tekstowa, podałem prawdopodobnego autora, przedstawiłem zarys treściowy oraz przytoczyłem odzwierciedlające meritum problematyki fragmenty artykułów. Wyjątek stanowią krótkie zdania, mające charakter hasłowy, które zamieszczam w całości.

1. „Zachodnie granice wyznaczy nam zwycięska koalicja — wschodnie wywalczyć możemy tylko sami’” (s. 1) — prawdopodobnie Józef Mackiewicz

2. Tekst wstępny (s. 1-3) — Józef Mackiewicz

Niemiecka polityka w stosunku do Polaków jest tępa i głupia. Bolszewicka jest perfidna i mądra. Niemcy nas konsolidują przeciwko sobie. Bolszewicy rozkładają. Niemcy robią z nas strzelających bohaterów. Bolszewicy (jak to wykazały smutne doświadczenia na Ziemiach Wschodnich) tchórzliwych niewolników. Niemcy przegrały wojnę. Bolszewicy ją wygrywają. Niemcy odchodzą. Bolszewicy przychodzą! $!^{10}$

3. KIEDY SKOŃCZY SIĘ WOJNA? (s. 3) - Józef Mackiewicz

Tekst Mackiewicza przewrotnie odpowiada na postawione w tytule pytanie:

[...] Do rychłego końca wojny wzdychać słusznie mogą wszyscy na globie ziemskim,

\footnotetext{
${ }^{8}$ O kontaktach W. Lipińskiego z J. Mackiewiczem w książce Marka Gałęzowskiego „Wzór piłsudczyka". Wacław Lipiński 1896-1949. Żotnierz, historyk, działacz polityczny, Warszawa 2001, s. $174 \mathrm{i}$ in.

9 „Alarm”, s. 1.

${ }^{10}$ Tamże, s. 3.
} 
za małym wyjątkiem. Do tego wyjątku należeć powinni Polacy. Nie kiedy się ona skończy, ale jak się ona skończy, jest dla nas kwestią najważniejszą. [...] Nasza karta jest bita na forum międzynarodowym, niestety. Aleśmy nie przegrali jeszcze, pozostało nam jeszcze tyle kapitału, którym operując w sensownych stawkach, odbić możemy przegraną. Jeszcze zasiadamy przy stoliku. Gdybyśmy od niego wstali dzisiaj, wstalibyśmy przegrani. Ale na szczęście gra trwa dalej. Na szczęście dla nas. Jest złym patriotą i złym Polakiem ten, który tęskni do jej przerwania ${ }^{11}$.

\section{PROPAGANDA SOWIECKA MA RACJĘ (s. 3) — Józef Mackiewicz}

Autor notatki porównuje wybory we wschodniej Polsce w latach 1939/40 za przyłączeniem do Związku Sowieckiego i hipotetycznymi wyborami pod okupacją niemiecką za przyłączeniem ziem polskich do III Rzeszy.

Czy możemy sobie wyobrazić taki terror niemiecki, który by zmusił całą ludność Polski do głosowania za przyłączeniem do Niemiec? Terror wyobrazić sobie możemy. Tłumy Polaków idących do urn wyborczych — nigdy! Ilu jest przyjaciół Niemiec w Warszawie, a ilu przyjaciół Bolszewików? Porównajmy te dwa regim’y i odpowiedzmy szczerze na pytanie: który z wrogów jest niebezpieczniejszy ${ }^{12}$.

5. „W praktyce międzynarodowej nie ceni się przyjaciół całkowicie oddanych"13 (s. 3) - Wacław Lipiński

\section{OTWIERAMY DYSKUSJĘ (s. 4-5) - Barbara Toporska}

Autorka przedstawia najważniejsze założenia działu WOLNA TRYBUNA. Nawiązuje do podtytułu „Alarmu” — „Ponadpartyjny organ walki z bolszewizmem”, który stanowi jasne, klarowne określenie celu wydawania czasopisma, wyrażającej „nasze” zdanie - obojga Mackiewiczów, redagujących to czasopismo ${ }^{14}$. Oczywiście można przyjąć, że wszystkie teksty wyszły spod ręki Józefa Mackiewicza, poza identyfikowalnymi w stu procentach (Wacław Lipiński, Aleksander Bocheński), jednak użycie liczby mnogiej wskazuje przynajmniej na współautorstwo Barbary Toporskiej, bowiem artykuły pisane przez Józefa Mackiewicza operują liczbą pojedynczą.

Wychodzimy z założenia, że praca dla Polski w obecnej Jej sytuacji to nie jakaś specjalna zasługa, czy przywilej partyjny, a obowiązek każdego Polaka. Do udziału w walce o wyzwolenie naszej Ojczyzny dopuszczony powinien być każdy w równym stopniu, bez różnicy jego przekonań politycznych, tym mniej jego przynależności partyjnej. Nie czas (i miejsce!) w tej chwili na małe porachunki i drobne zemsty. Nic tak nie gubi myśli politycznej jak namiętności nie kontrolowane przez rozum i doświadczenie. [...] W dobie obecnych kolosalnych przeobrażeń, nie tylko politycznych ale wprost myślowych, pomiędzy buforami tak potężnych przekształceń, jakimi są Niemcy hitlerowskie i Rosja komunistyczna, tkwienie w przestarzałych formach politycznych, stanowi poważne dla nas niebezpieczeństwo. [...] Nie mamy też zamiaru wypowiadać wojny podziałowi myśli politycznej na stronnictwa i partie, to znaczy grupowaniu się ludzi o podobnych przekonaniach. Dążyliśmy raczej do skasowania dyscypliny partyjnej, tej dyscypliny, o której powiedzieliśmy, że dla jej źle pojętego zachowania, wyrzeka się często

\footnotetext{
${ }^{11}$ Tamże.

${ }^{12}$ Tamże.

${ }^{13}$ Por. Gwido (Wacław Lipiński), Bilans, s. 17. Oryginalny zapis ma następujące brzmienie: „[...] W polityce międzynarodowej nie ceni się przyjaciół całkowicie oddanych. [...]”.

${ }^{14}$ Barbara Toporska we wstępie do zbioru felietonów Józefa Mackiewicza pt. Fakty, przyroda i ludzie, Londyn 1993, s. 5, napisała: ,[...] Oprócz drukowanych tekstów (nie tylko w języku polskim) były tam w niej [czyli gdzie? chodzi o jakąś teczkę? - B. K.] dokumenty cenne: m.in. trzy numery wydawanego przez nas wiosną-latem 1944 r. nielegalnego »Alarmu« [...]”.
} 
najsłuszniejszych haseł, li tylko dlatego, że są głoszone przez stronnictwa konkurencyjne. W jednym tylko wypadku jesteśmy świadkami imponującego frontu. Cała Polska i wszelkie jej ugrupowania w kraju i za granicą zjednoczone są w granitowym bloku przeciw-niemieckim. - Jakkolwiek niebezpieczeństwo sowieckie uważamy za wielokrotnie większe, to już chociażby równie zgodny front przeciwko jemu, uważalibyśmy jako wielki krok naprzód. [...] Naszym zadaniem jest tą lukę wypełnić, uwszechstronnić ciążące nad nami zagadnienie. Dlatego łącznie z wezwaniem do zjednoczenia , otwieramy lamy naszego pisma dla szerokiej dyskusji w „Wolnej Trybunie” $[\ldots]^{15}$.

\section{porska}

7. POPULARNE BŁĘDY, KTÓRE ZWALCZAĆ NALEŻY (s. 5) - Barbara To-

W tej rubryce piętnować będziemy zasłyszane powiedzonka, z którymi ze względu na brak miejsca nie możemy polemizować, a które uważamy za szkodliwe, za demobilizujące wobec niebezpieczeństwa bolszewickiego, wybielające Sowiety, jednym słowem — służące wrogiej propagandzie ${ }^{16}$.

8. „Żadnej współpracy z Bolszewikami!"17 (s. 5) — prawdopodobnie autorem jest Józef Mackiewicz

\section{DLACZEGO BOLSZEWICY SĄ STRASZNI? (s. 5-6) — Józef Mackiewicz}

[...] Żyliśmy zgnębieni, bezsilni, zawstydzeni własną bezsilnością i każdym odruchem, podyktowanym instynktem samozachowawczym, który w mechanizmie ustroju sowieckiego musiał być kompromisem, żyliśmy, nie, zdychaliśmy powoli, bez patosu, bez bohaterstwa, za zatrzaśniętymi drzwiami Europy, wierząc i nie wierząc na przemian, czy w te zaryglowane drzwi ktoś od zewnątrz uderzy, czy je na czas wywali [...] To był nastrój, jaki zastał wróg nr 1, Niemcy, uwalniając połowę Polski spod jarzma bolszewickiego. Nie, za tym wyświechtanym przez propagandę niemiecką zwrotem nie chcemy ukryć żadnej ironii. Bo nie o to chodzi, który terror jest krwawszy: czerwony czy brunatny? (pewno brunatny). Co jest gorsze: Gestapo czy NKWD? (pewno Gestapo). - Niemcy wyzwoliły nas na wschodzie z najgorszego jarzma, bo z własnej bezsilności, przerwały proces gnicia - to jest ta właśnie wschodnia zaraza, której bakterie działają paraliżująco na mózg i wolę - skonsolidowały całe społeczeństwo (oczywiście przeciw sobie - Niemcy konsolidują wszystkich przeciw sobie), zmobilizowały i rehabilitowały. [...] Otóż w naszej sytuacji, między Niemcami a Rosją sowiecką, dziesięciokrotnie, stokrotnie większe niebezpieczeństwo grozi ze strony SSSR niż Niemiec. Bo żaden Polak nie może stać się ideowym Niemcem, natomiast każdy może być ideowym komunistą. [...] Niemiecki narodowy-socjalizm nie ma w sobie nic atrakcyjnego dla podbitych narodów. Związek Sowiecki posiada tych atrakcyjności wiele i to stanowi bodaj jedno z największych niebezpieczeństw ${ }^{18}$.

10. „Zasadą polskiej polityki zagranicznej jest szukanie przeciwko Niemcom sprzymierzeńców na zachodzie Europy, nigdy na Wschodzie"19 (s. 6) — Wacław Lipiński

15 „Alarm”, s. 4-5.

${ }_{16}$ Tamże, s. 5.

${ }^{17}$ Można przyjąć, że hasła niesygnowane przez Gwido (Wacława Lipińskiego) są autorstwa Józefa Mackiewicza, choć niewykluczone, że są również pokłosiem jego rozmów z ppłk. Wacławem Lipińskim.

${ }^{18}$ Tamże, s. 5-6.

${ }^{19}$ Por. Gwido (Wacław Lipiński), Bilans, s. 18. Oryginalny zapis ma następujące brzmienie: „[...] Polityką zagraniczną kierują nie tylko ludzie. Kierują nią również zasady. W Polsce te zasady nakazują szukać sprzymierzeńców przeciwko Niemcom na zachodzie Europy, n i g d y na Wschodzie [...]". 


\section{W ROZSTRZYGAJĄCEJ CHWILI (s. 6-8) - Józef Mackiewicz}

[...] Jesteśmy przekonania, że jakakolwiek pozycja Polski jest w tej chwili wyjątkowo trudna i skomplikowana, tym niemniej nie jest ona beznadziejna. Sytuację zaciemnia fatalna formuła, że bolszewicy są ,,sojusznikami naszych sojuszników”. [...] Życie zadaje kłam temu twierdzeniu. W rzeczywistości nic nie stoi na przeszkodzie ku temu, aby „,przyjaciele naszych przyjaciół” mogli być jednocześnie naszymi zażartymi wrogami. Właśnie stanowisko Sowietów wobec Polski jest tego najlepszym dowodem. Toteż powinniśmy przyjąć formułę inną: bolszewicy są ,wrogami naszych wrogów”. (I wrogami wrogów naszych sojuszników.) [...] Idealna sytuacja byłaby taka, w której dane by nam było odegrać w wojnie sowiecko-niemieckiej rolę języczka u wagi. A możliwość ta, przynajmniej w obecnych warunkach, nie istnieje, nie jest po prostu realna ${ }^{20}$. W tej sytuacji Mackiewicz proponuje ogłoszenie neutralności Polski wobec konfliktu niemiecko-sowieckiego: tzn. tego rodzaju stanowiska, które by doczekało się klęski Niemiec na Zachodzie, zanim bolszewicy zaleją nasz kraj i ogłoszą go jako Republikę Czerwoną, w myśl haseł Karty Atlantyckiej „, o wyrażeniu woli ludności”, którą to wolę po mistrzowsku potrafią fałszować. W ten sposób wojna $\mathrm{z}$ Niemcami mogłaby się zakończyć przed początkiem dramatu Polski. [...] Wojna niemiecko-sowiecka nie jest wojną naszą. Naszą wojną jest tocząca się pomiędzy Niemcami a naszymi zachodnimi Aliantami i do niej należymy, należymy od pierwszego jej dnia. Do tej wojny wnosić powinniśmy zgodny wysiłek całego Narodu i drogocenna ofiarę krwi naszych żołnierzy. [...] Tego rodzaju stanowisko Polski zwiększa szanse, iż pożoga wojenna oszczędzi nasz kraj. Oszczędzi nam również wiele cennej młodzieży potrzebnej nam nie tyle „,na niemieckich tyłach", co w przednich szeregach polskich. Ocalona przed zalewem bolszewickim Polska doczekać się może w ten sposób chwili, w której całe swe siły skierować będzie mogła we właściwym kierunku, w tym mianowicie, którego na razie przesądzać nie możemy, a który zostanie ustalony jedynie i wyłącznie przez nieskrępowaną polską rację stanu. [...] Zwekslowanie epilogu wojennego na zachodni front wojenny da Polsce przede wszystkim tę wielką korzyść, że pokój który nastąpi, nie będzie podyktowany przez Sowiety. W konkluzji artykułu, czytamy: [...] współpraca Armii Krajowej z bolszewikami byłaby niczym innym, jak pchaniem młodzieży polskiej na sowiecką gilotynę i to w formie dla bolszewików najbardziej dogodnej, bo umożliwiającej im branie nas i niszczenie gołymi rękami ${ }^{21}$.

12. HERSZT PRZYJMUJE ZDRAJCÓW I SPRZEDAWCZYKÓW Agencja „A” donosi (s. 8) - prawdopodobny przedruk z serwisu informacyjnego BIP AK ANTYK. Tematem jest bankiet wydany na Kremlu z okazji przemianowania I Dywizji im. Tadeusza Kościuszki na I Armię Wojska Polskiego.

13. TEORIA OPORU PRZECIWKO NAJEŹDZCOM (s. 9-12) - X. Y. — Aleksander Bocheński

Autorem tego najdłuższego, składającego się z czterech stron artykułu jest publicysta Aleksander Bocheński. Kopia tego tekstu została odnaleziona w jego prywatnym archiwum i jest sygnowana własnoręcznym podpisem autora. Tekst został umieszczony w „Wolnej Trybunie”, gdyż redakcja nie podzielała poglądów Bocheńskiego. Zapowiedziano replikę w jednym z najbliższych numerów „Alarmu”. Autor prezentuje następujące tezy:

[...] Cel oporu narodowego może być dwojaki: na zewnątrz i na wewnątrz. Nacisk na najeźdźce i propaganda zagraniczna, oto cele oporu zewnętrznego. Podtrzymywanie ducha, oto cel oporu wewnętrzny. Jednakże opór wywołuje pewną reakcję u najeźdźcy,

\footnotetext{
20 „Alarm”, dz. cyt., s. 6-7.

${ }^{21}$ Tamże, s. 7-8.
} 


\begin{abstract}
i ta reakcja $z$ kolei wpływa na stan ducha narodu ujarzmionego. Oto schemat, który nie wolno nam nigdy tracić z oczu. [...] Czym jest duch narodowy, dla podtrzymania którego należy wywołać opór? Jest nim więź łącząca poszczególne jednostki należące do danego narodu. Brak ducha narodowego sprawia, że naród jest jak sypki piasek, nie łączy go żaden cement, każdy dba tylko o siebie samego, o swój własny interes, nikt nie chce poświęcić interesu osobistego dla interesu zbiorowego, przyszłego. I dalej: Utrzymanie i rozwój więzi ofiarności — czyli ducha narodowego jest środkiem koniecznym do wydobycia siły z narodu. [...] Celem działania sił narodowych jest rozwój narodu, i zapewnienie mu wyższego szczebla w hierarchii międzynarodowej ${ }^{22}$.
\end{abstract}

W dalszej części wywodu autor omówił warunki, jakie umożliwiają oraz hamują rozwój ducha narodowego, opierając się na klasykach XIX-wiecznej polskiej myśli politycznej. Prezentuje w tym kontekście interesującą tezę Ludwika Mierosławskiego, którą następnie poddaje miażdżącej krytyce:

[...] opór, i skutki oporu w postaci prześladowań, pomagają walnie do rozwoju ducha narodowego. Natomiast brak oporu, i brak prześladowań, ducha zabija ${ }^{23}$. Bocheński konkluduje: Przede wszystkim musimy uczynić wszystko możliwe, by sąsiedzi nasi zrozumieli, że jesteśmy narodem myślącym, tak jak Czesi, Rumuni czy Węgrzy, że nasze stanowisko jest funkcją warunków i ich poczynań, że stosujemy opór dlatego, że nie posiadamy na razie minimum tego, co potrzeba nam do zachowania sił narodowych, nie zaś dlatego, że ktoś kiedyś napisał wiersz o tym, że trzeba bez względu na siły i szanse, walczyć z „odwiecznym” wrogiem tak długo, póki naród nasz nie uzyska celów chwilowo niemożebnych do zdobycia, lub też nie spowoduje sąsiadów do totalnego przesiedlenia i wyniszczenia go ${ }^{24}$.

14. TUWIM I KIEPURA NA CZELE RZĄDU Agencja „A” (s. 12) — prawdopodobnie przedruk z BIP AK ANTYK

\title{
15. „PRZEŁOM” (s. 12-13) — Józef Mackiewicz
}

Niezwykle interesująca wydaje się reakcja Józefa Mackiewicza na ukazujący się w Krakowie dwutygodnik „Przełom” redagowany przez Jana Emila Skiwskiego.

[...] Wolno mu z polskiego punktu widzenia krytykować rząd Premiera Mikołajczyka, wolno mu demaskować zdemaskowaną grę Moskwy, tylko o Hitlerze, Franku, o Rosenbergu i Himlerze - nie. Wolno mu biadać nad połową Polski za linią Curzona, ale o drugiej połowie musi milczeć. Słowem, wolno mu tylko jedną nogą stać na polskiej platformie politycznej. [...] Wobec zapoznania się jednak z dalszą pracą Przełomu doszliśmy do wniosku, że p. Skiwski nie stoi na stanowisku przyszłej suwerenności Polski, a więc przestaje nas interesować. Na temat niepodległości czy poddaństwa Polski można jeszcze polemizować z panami z Völkischer czy Das Reich, ale nie z panami z Przełomu ${ }^{25}$.

16. „Wobec zjednoczonych Narodów nie jesteśmy petentem, ale kontrahentem”26 (s. 13) - Wacław Lipiński

\footnotetext{
22 Tamże, s. 9-10.

${ }^{23}$ Tamże, s. 10.

${ }^{24}$ Tamże, s. 12.

${ }^{25}$ Tamże, s. 13.
}

${ }^{26}$ Por. Gwido, Bilans, s. 24. Oryginalny zapis ma następujące brzmienie: ,[...] Francji należało sprezentować rachunek za niedotrzymanie wojskowej umowy paryskiej, Anglii za lotniczą pasywność, obydwom - za fałszywe i błędne informowanie, za fałszywą i błędną ocenę położenia. Stanąć należało nie w postawie petenta, zawstydzonego położeniem i upokorzonego klęską 
17. GEN. SOSNKOWSKI (s. 13) - przedruk z „Tydzień” + komentarz Józefa Mackiewicza, informujący o decyzji Rady Narodowej o rozdzieleniu funkcji Naczelnego Wodza i Następcy Prezydenta Rzeczpospolitej, co wydaje się na rękę propagandzie sowieckiej.

18. „Zdobywając Cassino, wypełniliśmy tylko obowiązek wobec sojusznika, którego Anglia i Francja nie wypełniły we wrześniu 1939 roku”27 (s. 13) - Wacław Lipiński

\section{SZKICE SYTUACYJNE / Próba analizy/ (s. 14-16) — Józef Mackiewicz}

[...] Wychodzimy z założenia, że Niemcy wojnę przegrały. Ale interesuje nas bardziej nie to, kiedy ją przegrają, tylko - jak ją przegrają. — Czy możemy na przykład chcieć, aby w wyniku tej przegranej, marszałek Stalin w otoczeniu czerwonych sztandarów wkraczał do Berlina? Nigdy! ${ }^{28}$ W związku z lądowaniem wojsk anglosaskich w Normandii napisał: [...] wybór miejsca na zachodnim cyplu Francji, jest z punktu naszych interesów najfatalniejszy. Oddala nas bowiem od naszych sojuszników, wydając całkowicie na łup Sowietów. Sytuacji nie zmieniłaby w tym względzie okoliczność nie raptownego, a powolnego załamywania się frontów niemieckich. Albowiem na zachodzie Niemcy mogliby się jeszcze długo opierać na linii Alp i tzw. linii „Zygfryda”, podczas gdy bolszewicy zalewaliby stopniowo Bałtykę, Polskę, Czechy i Bałkany. Z tego punktu widzenia, jak też z tego, że winniśmy wkraczającym wojskom czerwonym stawiać stanowczy opór, leżałoby w naszym interesie, aby Alianci na miejsce inwazji wybrali takie terytorium europejskie, które by się znajdowało najbliżej Polski. Lepiej już z Włoch przez Austrię, z Norwegii przez Danię i Gdańsk. Najlepiej ze Szwecji i z Bałkanów. W ten sposób armie Wodza Naczelnego gen. Sosnkowskiego mogłyby się znaleźć w Polsce przed albo równocześnie z bolszewikami ${ }^{29}$. Dalej analizuje przyczyny siły Sowietów, dowodząc, że Armia Czerwona składa się z „szeregowych-zawodowych”, systemowo przygotowanych do pełnienia tej roli w skoszarowanym i bezwolnym społeczeństwie sowieckim. W podsumowaniu tekstu czytamy: Front wschodni zaistniał dla nas nie z dniem 22 czerwca 1941 r., a z dniem 17 września 1939 roku. Od tej chwili, zważywszy na różnice potencjalne naszych dwóch wrogów, stał się frontem głównym. Być może, już w roku 1940 interesy nasze leżały bardziej na linii Mennerheima, niż na linii Maginota. [...] Nasz polski front wschodni mógłby nie istnieć tylko w jednym wypadku, mianowicie w tym, gdyby pobicie Niemiec było celem samym w sobie. Ale dla nas pobicie Niemiec nie jest celem, tylko jednym ze środków do celu. Celem wojny, którą prowadzimy, jest odrodzenie potężnej, niepodległej, suwerennej Rzeczypospolitej Polskiej. - Temu świętemu celowi, zagraża w tej chwili bardziej niż w latach poprzednich, front wschodni ${ }^{30}$.

20. „Dziś w obliczu zaborczych żądań sowieckich Naród Polski ma tylko jedną odpowiedź: Odrzucamy kategorycznie koncepcje sowieckie nazywane »linią Curzona«,

lecz w postawie kontrahenta, którego partnerzy opuścili, któremu nie dotrzymali umownych warunków. W postawie atakującej i oskarżającej, nie w obronnej i tłumaczącej [...]".

27 Por. Gwido, Bilans, s. 24. Zdanie jest parafrazą przytoczonego powyżej (przypis 29) fragmentu. Biorąc pod uwagę datę wydania broszury, Wacław Lipiński nie mógł wspomnieć o bitwie pod Monte Cassino.

\footnotetext{
28 „Alarm”, s. 14.

29 Tamże, s. 15.

${ }^{30}$ Tamże, s. 16.
} 
stoimy zdecydowanie na gruncie nienaruszalności i granic ustalonych Traktatem Ry-

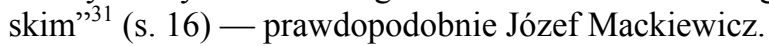

\section{Podsumowanie}

Spośród trzech wydanych w czerwcu-lipcu 1944 roku numerów „Alarmu” znany jest tylko pierwszy, programowy. Pocieszający jest fakt zlokalizowania i wydania napisanej przez Józefa Mackiewicza w październiku 1944 roku broszury Optymizm nie zastapi nam Polski, gdzie rozwija on wątki poruszane w „Alarmie”. Niezwykłą wartością odnalezionego numeru jest poznanie sposobu oceny rzeczywistości, kształtowania perspektywicznych koncepcji politycznych czasu przed powstaniem warszawskim w rozgorączkowanym oczekiwaniem mieście. Czy te koncepcje Mackiewiczów miały jakiekolwiek szanse na realizację? Czy to, co się później stało, nie było konsekwencją rozwinięcia myśli Aleksandra Bocheńskiego, publikującego w „Wolnej Trybunie”? Adresaci ...,trzeba było"... niebawem zapełnili więzienia NKWD i Informacji Wojskowej, a niektórzy poszli na jawną i tajną współpracę z Sowietami i ich agenturą, wbrew przysiędze składanej na wierność Rzeczpospolitej.

\section{LITERATURA}

Bąkowski M., Wstęp do bibliografii, czyli o roli donosów policyjnych w badaniach literackich, [w:] J. Mackiewicz, Nudis Verbis, Londyn 2017.

Gałęzowski M., ,,Wzór piłsudczyka”. Wacław Lipiński 1896-1949. Żolnierz, historyk, działacz polityczny, Warszawa 2001.

GWIDO (Lipiński W.), Bilans czterolecia 1939-1944, Warszawa — styczeń 1944.

Karsov N., Od Wydawcy, [w:] J. Mackiewicz, Nudis verbis. SUPLEMENT, Londyn 2017.

„Alarm”, [w:] J. Mackiewicz, Nudis verbis. SUPLEMENT, Londyn 2017.

Mackiewicz J., Nudis verbis, [w:] Nudis verbis, Londyn 2017.

Mackiewicz J., Optymizm nie zastapi nam Polski, Dzieła, t. 18, Londyn 2015.

Mackiewicz J., Spotkanie z Lipińskim, [w:] Nudis verbis, Londyn 2017.

\section{THE RECOVERED FIRST ISSUE OF JÓZEF MACKIEWICZ AND BARBARA TOPORSKA'S ALARM}

A copy of the first issue of the periodical Alarm, published by Józef Mackiewicz and Barbara Toporska between June and July 1944 in Warsaw, was found in October 2017. The article consists of two main parts. The first presents the origin and structure of the Alarm and the condition of the copy; it also discusses the reasons for considering it to be a work of Józef Mackiewicz and Barbara Toporska. The second part offers a detailed presentation of the contents and message of the articles, as well as identifies their authors.

KEY WORDS: Alarm, Bolshevism, anti-communism, Józef Mackiewicz, Barbara Toporska, Wacław Lipiński, Aleksander Bocheński, GWIDO, Home Army, Germany, Soviet Union, Polish Committee of National Liberation, Allies, USA, Atlantic Charter, Nina Karsov.

SŁOWA KLUCZOWE: „Alarm”, bolszewizm, antykomunizm, Józef Mackiewicz, Barbara Toporska, Wacław Lipiński, Aleksander Bocheński, GWIDO, Armia Krajowa, Niemcy, Sowiety, PKWN, Alianci, USA, Karta Atlantycka, Nina Karsov

\footnotetext{
${ }^{31}$ Por. przypis 23.
} 